\title{
Cavernous Hemangioma of the Face
}

National Cancer Institute

\section{Source}

National Cancer Institute. Cavernous Hemangioma of the Face. NCI Thesaurus. Code C7053.

A cavernous hemangioma arising from the face. 